\title{
下水污泥焼却灰の硫酸抽出液からの電気透析法 による金属類除去と水溶性リン酸塩の生成
}

\author{
伊藤 歩 1 川上上 北斗 2 -石川 奈緒 ${ }^{3}$ 用山 徳美 4 ・落 修一 5 海田 輝之 6 \\ 1正会員 岩手大学大学院准教授 工学研究科フロンティア材料機能工学専攻（テ020-8551 岩手県盛岡市 \\ 上田4-3-5) \\ E-mail: aitou@iwate-u.ac.jp \\ 2正会員（株）ドーコン（三004-8585 札幌市厚別区厚別中央1条5丁目4番1号） \\ 3 (株) 正会員 岩手大学助教 理工学部システム創成工学科社会基盤・環境コース（テ020-8551 岩手県 \\ 盛岡市上田4-3-5) \\ E-mail: naoki@iwate-u.ac.jp \\ 4非会員 日本燐酸（株）（厂299-0266 千葉県袖浦市北袖14） \\ 5正会員 (公財) 日本下水道新技術機構（テ162-0811 東京都新宿区水道町3番1号 水道町ビル 7 階） \\ E-mail:s-ochi@jiwet.or.jp \\ 6正会員 岩手大学教授 理工学部システム創成工学科社会基盤・環境コース（テ020-8551 岩手県盛岡市 \\ 上田4-3-5) \\ E-mail: umita@iwate-u.ac.jp
}

電気透析装置を用いて下水污泥焼却灰の硫酸抽出ろ液に含まれる $\mathrm{Al}$ やの他の金属の除去を試験した結 果，抽出ろ液のpHを0.5に維持し，電気透析時間を10時間とすることで， $\mathrm{Al}$ や $\mathrm{Zn}, \mathrm{Cu}, \mathrm{Cd}, \mathrm{Ni}$ の 85 ～95\% 程度を除去でき, $\mathrm{P}$ の $60 \%$ 程度を保持できた. 電気透析後の硫酸抽出ろ液を $\mathrm{NH}_{3}$ 水で中和した後, 乾燥させ て得られた粉末試料の水溶性Pの含有率は, $90 \%$ 程度であり, $\mathrm{P}$ の大部分を速効性のP化合物として回収で きた。粉末試料をXRDとFE-SEMでそれぞれ分析した結果, $\left(\mathrm{NH}_{4}\right)_{2} \mathrm{SO}_{4}, \mathrm{NH}_{4} \mathrm{H}_{2} \mathrm{PO}_{4}$ および $\mathrm{P}_{2} \mathrm{O}_{5}$ の回折パタ ーンと類似したピークが観察され, 元素マッピングではNの分布とは重ならないPの分布も確認されたこ とから, 粉末試料中のSとPの大部分は上記の化合物として存在していると推察された.

Key Words : Sewage sludge incinerated ash, phosphorus recovery, extraction with sulfuric acid, metals removal, electrodialysis

\section{1. はじめに}

日本は国内で消費されるリン（P）のほぼ全てを海外 からの輸入に依存しており，価格の高騰や将来的なリン 鉱石の枯渇あるいは品質低下の問題などから，持続可能 なリン資源の確保が求められている。国土交通省が取り まとめた「下水道におけるリン資源化の手引き」 ${ }^{1)}$ ると, リン鉱石, リン酸系肥料および食糧・飼料として 年間 55.5 万トン (2006 年) の P が輸入されており, そ のうちの約 1 割が下水道に流入し，更にその約 7 割に相 当する 4 万トンの P が下水污泥に移行していると推定さ れている. 日本では下水污泥の発生固形物量の約 7割が 焼却処理されており ${ }^{2}$ ， その焼却灰（以下，下水灰とす る）に残存する P の含有率は 5～15\%に達する ${ }^{1)}$. そこ で，下水灰を対象としたリン回収技術が開発されてきて いる.
岐阜市では灰アルカリ抽出法によるリン回収が実用化 されている. 本手法ではアルカリ溶液によって下水灰中 の $\mathrm{Al}$ と $\mathrm{P}$ を抽出した後, $\mathrm{P}$ を肥料として利用可能なリ ン酸カルシウム塩として回収できる ${ }^{3)}$ 5). しかしながら, P の抽出には加熱を必要とし，その抽出率は 50\%程度で あり，アルカリ溶液では抽出されない重金属類が処理後 の灰に残存するといった欠点がある. 一方，酸（主に硫 酸）を用いた抽出法も広く検討されており，下水灰の $\mathrm{pH}$ を 1～2 程度に低下寸ることで 80～90\%程度の P を抽 出できる の 11). 抽出後は共存する $\mathrm{Al}$ や他の重金属類と の分離が必要であり，P をリン酸アルミニウム ${ }^{7) や リ ン ~}$ 酸第二鉄 91, 10)の化合物として回収できるが，これらの沈 殿物は溶解度が低いため肥料原料としてそのまま利用す ることは難しい，そのため，陽イオン交換樹脂 ${ }^{12)}$ $\mathrm{Zr}(\mathrm{IV})$ 含有吸着剂 ${ }^{13)}$ を用いて硫酸抽出液中の重金属類を 除去する方法が検討されており，重金属に加えて $\mathrm{Al}$ も 
除去されたリン酸濃縮液として回収できることも報告さ れている ${ }^{14}$. しかしながら，これらの方法では重金属類 の濃度が $\mathrm{g} / \mathrm{L}$ オーダーの場合, 相当量の吸着剤が必要で あるとともに，かなりの頻度で吸着凨の再生を行う必要 があり, 効率的な方法であるとは必ずしも言えない.

イオン交換材料の再生が不要な技術として, 食塩の濃 縮回収に利用されているイオン交換膜を用いた電気透析 法があげられる．下水灰と硝酸の混合賏濁液を電気透析 装置に投入して金属イオンとリン酸イオンを分離する試 みが検討されている ${ }^{15 \sim 17) か ゙ ， 1 ２ ~}$ 週間程度の時間を要 寸ることが報告されている．著者らも下水灰の硫酸抽出 液のろ液を対象として, そのろ液に陽イオンとして存在 する金属イオンを除去し， $\mathrm{P}$ をリン酸 $\left(\mathrm{H}_{3} \mathrm{PO}_{4}\right)$ として 保持するための電気透析装置を試作して検討を進めてき た. その結果, 抽出ろ液の $\mathrm{pH}$ を調整せずに電気透析を 行うことによって抽出ろ液の $\mathrm{pH}$ が上昇し， P の損失が 大きくなるが，pH を $0.5 〜 1$ 程度に維持することによっ て 10 時間程度で $\mathrm{P}$ を抽出ろ液に保ちながら $\mathrm{Al}$ などの陽 イオンを除去できることを報告している ${ }^{18)}$. 金属類を除 去した後の抽出ろ液に残存するリン酸と硫酸を最終的に はリン安と硫安を含む化成肥料の原料として利用するこ とを想定した場合, リンを水溶性固形物として回収寸る ことが利用の面からも望ましいと考えられる。

以上より, 本研究では下水灰の硫酸抽出ろ液について 異なる時間で電気透析を行った後，それらのろ液を回収 して $\mathrm{NH}_{3}$ 水による中和と乾燥による固形物化を検討し た. 更に回収した固形物の粉末試料に含まれる水溶性リ ンの存在率を調查するとともに X 線を利用した分析技 術による粉末試料の構成成分の推定を行った.

\section{2. 実験方法}

\section{(1) 実験材料}

本研究に用いた下水灰は, 愛知県内の下水処理場から 採取したものであり，含水率が約34\%であった，なお， 上記の処理場は, 比較的多量の試料を入手でき, 大都市 圈内に位置することから選定した. また，下水灰の保管 期間として4年程度のものを使用したが，保存期間 1 カ月 程度のものと比較しても元素類の抽出率に大きな差はみ られなかった. 下水灰の元素類の含有量を把握するため に, ICP-OES (Shimadzu, ICPE-9000), ICP-MS (Thermo Fisher, iCAP-Qc)による元素類の分析を行った. 分析は, 下水試験方法 ${ }^{19}$ に従って下水灰を塩酸と硝酸で前処理し た後, $0.45 \mu \mathrm{m}$ のメンブレンフィルターでろ過し，その ろ液の希釈液に内部標準物質としてICP-OESではY，ICPMS (対象元素 : As, $\mathrm{Cd}, \mathrm{Cr}, \mathrm{Ni}, \mathrm{Pb}$ ) ではBi, $\mathrm{Ge}$, In を添加し, 内部標準法により行った. 表-1に下水灰の乾
燥重量当たりの元素類の含有量を示寸. 下水灰中の $\mathrm{P} の$ 含有率は $8 \%$ 程度であり, 主要な金属の含有率はAlが7\%, Feが6\%，Caが4\%，Mgが1\%であった．主な重金属の含 有率についてはZnが $0.4 \%, \mathrm{Cu}$ とnが $0.1 〜 0.2 \%$ であった.

表-1 下水灰の元素類の含有量と硫酸抽出率

\begin{tabular}{|c|c|c|c|c|c|c|c|}
\hline 元素 & $\mathrm{Al}$ & $\mathrm{Ca}$ & $\mathrm{Fe}$ & $\mathrm{K}$ & $\mathrm{Mg}$ & $\mathrm{P}$ & $\mathrm{Zn}$ \\
\hline $\begin{array}{c}\text { 含有量 } \\
(\mathrm{g} / \mathrm{kg}-\mathrm{Ds})\end{array}$ & 70.2 & 40.3 & 60.8 & 5.60 & 10.4 & 77.8 & 4.05 \\
\hline $\begin{array}{c}\text { 抽出率 } \\
(\%)\end{array}$ & 96.9 & 18.9 & 29.6 & 92.9 & 92.3 & 101.5 & 42.0 \\
\hline & & & & & & & \\
\hline 元素 & $\mathrm{As}$ & $\mathrm{Cd}$ & $\mathrm{Cr}$ & $\mathrm{Cu}$ & $\mathrm{Mn}$ & $\mathrm{Ni}$ & $\mathrm{Pb}$ \\
\hline $\begin{array}{c}\text { 含有量 } \\
(\mathrm{mg} / \mathrm{kg}-\mathrm{DS})\end{array}$ & 17.6 & 3.05 & 228 & 1360 & 1670 & 325 & 112 \\
\hline $\begin{array}{c}\text { 抽出率 } \\
(\%)\end{array}$ & 90.9 & 98.4 & 24.1 & 64.0 & 95.8 & 33.8 & 0.08 \\
\hline
\end{tabular}

\section{(2) 元素類の抽出実験}

下水灰からの元素類の抽出を行うために, $1 \mathrm{~L}$ の振と うフラスコで下水灰と純水を混ぜ合わせ，固形物濃度が 100 g-DS/L となるように下水灰懸濁液を調製した．硫酸 を用いて懸濁液の $\mathrm{pH}$ を 1 に調整した. その後, $25^{\circ} \mathrm{C} の$ 恒温室内で往復式振とう機を用いて 1 分当たり 120 回で 振とうし，回分式の抽出を 24 時間行った。一定時間毎 に $\mathrm{pH}$ の測定を行い, $\mathrm{pH}$ が設定值から外れている場合は

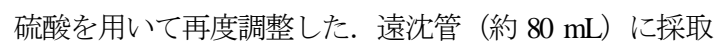
した試料を遠心分離 $\left(25^{\circ} \mathrm{C}, 3,000 \mathrm{rpm}, 10 \mathrm{~min}\right)$ した後, 上澄液を $0.45 \mu \mathrm{m}$ のメンブレンフィルターでろ過した.

このろ液を抽出ろ液とし, 次の電気透析実験に使用した。 抽出ろ液の元素濃度を上記と同様の方法により ICPを用 いて分析した. 表-1 に元素類の抽出率 (=抽出液の元素 濃度（表-3 の透析時間 $0 \mathrm{hr}$ の濃度）：含有量（表-1）－ 下水灰懸濁液の固形物濃度 $(0.1[\mathrm{~kg} / \mathrm{L}]) \times 100)$ を示す.

\section{(3) 電気透析実験}

図-1 に本実験に用いた電気透析装置の構成と電気透 析のイメージを示す. 装置は直流電源（エー・アンド・ ディ, AD8724D），透析セル，電極，電解槽で構成され， 透析セルのイオン交換膜には陽イオン交換膜（デュポン 社, Nafion PFEA Membrane (N117)）と陰イオン交換膜 （（株）アストン，ネオセプタ（AHA）），電極はメ ッシュ状のチタン・白金電極 $(9 \mathrm{~cm} \times 9 \mathrm{~cm})$ を使用し, 2 枚の陽イオン交換膜 $(12 \mathrm{~cm} \times 12 \mathrm{~cm})$ と 2 枚の陰イオ ン交換膜 $(12 \mathrm{~cm} \times 12 \mathrm{~cm})$ をそれぞれ交互に挟んで，中 間槽（100 mL），陽イオン回収槽（110 mL），陰イオン 回収槽 $(110 \mathrm{~mL})$, 外側の電極槽 $(1200 \mathrm{~mL})$ の 5 部屋 を作った. 中央に位置する中間槽に上記の抽出ろ液を加 え, 陽イオン回収槽, 陰イオン回収槽および外部電極槽 
には希硫酸（純水で希釈し $\mathrm{pH}$ を 0.5 に調整）を加えた. 図-1 に示すように通電後のイメージとしては中間槽内 の試料中の陽イオンは陰極に引き付けられ，陽イオン交 換膜を透過出来るが，陰イオン交換膜に遮断され，陽イ オン回収槽内に閉じ込められる. 他方, 陰イオンは陰イ オン回収槽内に閉じ込められる. そして $\mathrm{P}$ は $\mathrm{pH}$ が 0.5 程度であれば非解離性のリン酸 $\left(\mathrm{H}_{3} \mathrm{PO}_{4} \gtrless \mathrm{H}^{+}+\mathrm{H}_{2} \mathrm{PO}_{4}^{-}\right.$, $\left.\mathrm{p} K_{\mathrm{al}}=2.12^{20)}\right)$ として存在することから中間槽に留まると予 想した.

中間槽, 陽イオン回収槽および陰イオン回収槽の $\mathrm{pH}$ を測定（TOA DKK，HR-25M）できるように電解槽とは 別に 3 つビーカーを用意し, 各ビーカーと各槽をチュ ーブで繋ぎ，ローラー式定量ポンプ (Master Flex, 755370）を用いて試料を循環（72 mL/min）できる装置構成 とした（写真-1）. 陽イオンおよび陰イオン回収槽に接 続したビーカーには上述の希硫酸を $300 \mathrm{~mL}$ 加えた. 一 方, 中間槽に接続したビーカーには抽出ろ液を $150 \mathrm{~mL}$ 加え，ポンプで循環しながらビーカー内において抽出ろ 液の $\mathrm{pH}$ を希硫酸で 0.5 に調整した. 電流值を $2.7 \mathrm{~A}$ に設 定して通電を開始した後, 各槽の試料を経時的に採取し, 元素類の濃度について ICPを用いて分析した．また，硫 酸イオン $\left(\mathrm{SO}_{4}^{2-}\right)$ 濃度をイオンクロマトグラフ

（DIONEX，DX-500）で測定した。電気透析時間を 6 時 間と 10 時間の 2 条件に設定し, 電気透析終了後に抽出 ろ液を回収し, 次の固形物化実験に使用した。

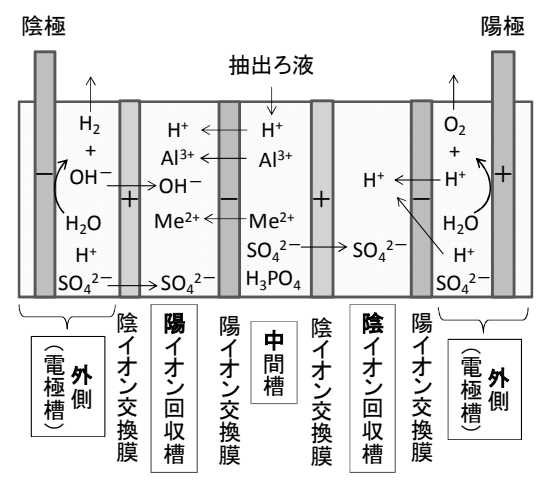

図-1 電気透析装置のイメージ

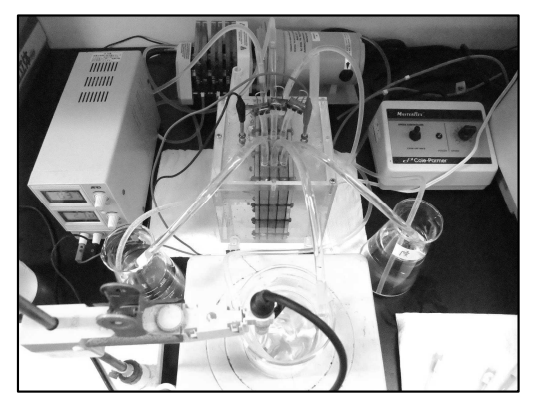

写真-1 実験装置の構成（写真中央 : 電解槽, 写真左 : 直流電 源, 写真手前 : $\mathrm{pH}$ 電極, 写真奥 : 定量ポンプ)

\section{(4) 抽出ろ液の固形物化実験}

電気透析後の抽出ろ液に残存するPとSを肥料原料と して利用可能な固形物として回収するために, 電気透析 後（6時間後と10時間後）の抽出ろ液を中間槽から取り 出し, $\mathrm{NH}_{3}$ 水で中和し, 硫酸イオンを硫安（硫酸アンモ ニウム : $\left.\left(\mathrm{NH}_{4}\right)_{2} \mathrm{SO}_{4}\right)$ ，リン酸イオンをリン安（リン酸 アンモニウム : $\mathrm{NH}_{4} \mathrm{H}_{2} \mathrm{PO}_{4}$ または $\left.\left(\mathrm{NH}_{4}\right)_{2} \mathrm{HPO}_{4}\right)$ あるいは五 酸化リン $\left(\mathrm{P}_{2} \mathrm{O}_{5}\right)$ として回収することを試みた. 電気透 析後の抽出ろ液50 $\mathrm{mL} \mathrm{NH}_{3}$ 水 $(28 \%)$ を $\mathrm{pH}$ が9.8になる まで滴下した. その際, 白色沈殿の生成が観察された. その後, この懸濁液を複数のガラス製シャーレに移して $45^{\circ} \mathrm{C}$ で24時間乾燥させ，析出物を回収し，乳鉢で粉末状 にした後，成分分析のため $110^{\circ} \mathrm{C} て ゙ 2$ 時間乾燥した（以下， 粉末試料とする）。粉末試料について，前述のICPによ る元素類の含有量と水溶性量の分析に加えて, XRD

(Rigaku, RINT $2200 \mathrm{VPC/IHK)}$ による粉末結晶の同定と FE-SEM（日本電子（株），JSM-7001F）と EDX

(OXFORD, INCA X-act）による元素マッピングを試み た. 水溶性元素量については肥料分析法（農林水産省農 業環境技術研究所法) ${ }^{21)}$ を参考に，粉末試料 $0.5 \mathrm{~g}$ と純水 $40 \mathrm{~mL} 30$ 分間混合した後，ろ過を行い，そのろ液を分

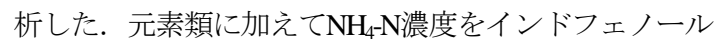
青吸光光度法によって自動分析装置で分析した.

\section{3. 実験結果および考察}

\section{(1) 電気透析による抽出ろ液からの金属類除去}

図-2に電気透析における各槽の $\mathrm{Al}$ と $\mathrm{P}$ の存在率の経時 変化を示す. 図中の存在率は各槽の元素量（=濃度 $\times$ 体 積）を中間槽の初期元素量で除したものである. なお, 計算に用いた各槽の任意の時間での体積を電気透析中に 把握することはできなかったため, 電気透析前後での体 積の増減分 $\left(\Delta \mathrm{V}=\mathrm{V}_{\mathrm{t}=0}-\mathrm{V}_{\mathrm{t}=10}, \mathrm{t}\right.$ : 透析時間 $\left.\left.\mathrm{hr}\right]\right)$ を全透析 時間 (=10[hr] $)$ で割り, それを各時間毎に案分した体積 $\left(\mathrm{V}_{\mathrm{t}=\mathrm{i}}=\mathrm{V}_{\mathrm{t}=0}+\Delta \mathrm{V} / 10 \times \mathrm{i}\right)$ を用いて各時間での存在率を求め た. また, 中間槽以外の各槽には希硫酸を加えているこ とから，中間槽以外の各槽の初期值は0とした。

$\mathrm{Al}$ の存在率は時間の経過とともに中間槽で減少する一 方で陽イオン回収槽で増加し，10時間目には約95\%のAl が中間槽内の抽出ろ液から除去され，陽イオン回収槽に 移動した.Pの存在量は中間槽で徐々に減少し, 陰イオ ン回収槽と陽イオン回収槽の双方に移動し，10時間目で は約60\%のPが中間槽に留まったが, 残りの40\%は他の 槽に移動し，上述の予想とは異なる結果となった。 
ロ中曰陽曰陰凹外左 凹外右
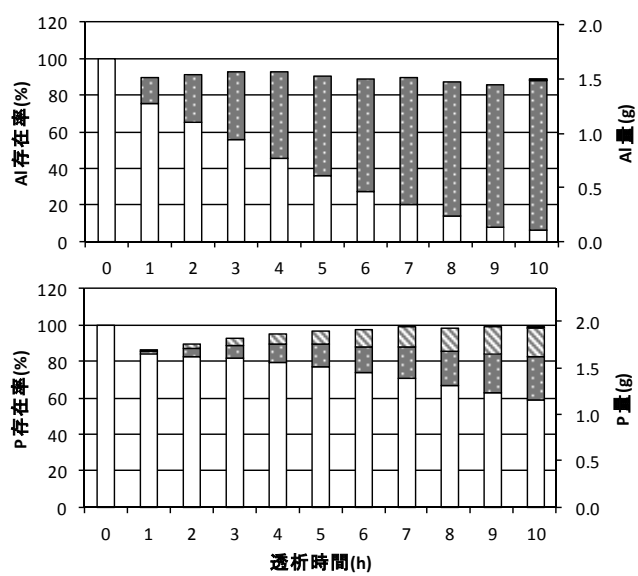

図-2 電気透析における各槽の $\mathrm{Al}$ と $\mathrm{P}$ の存在率の経時変化

表-2に電気透析前後での中間槽，陽イオン回収槽，陰 イオン回収槽および電極槽の溶液の体積変化とその変化 率を示す．変化率は電気透析後の体積を電気透析前の体 積で除したものである. 中間槽内のろ夜の体積は電気透 析によって減少し，その減少率は電気透析時間10hrで 36\%であった。一般に，電気透析ではイオン交換膜を介 してイオンだけではなく電気浸透水として水の移動も生 じる22．陽イオンおよび陰イオン回収槽の溶液の体積は 電気透析後に増加していることからも, 中間槽内のろ液 の一部が陽イオン回収槽と陰イオン回収槽に移動したと 考えられる．上述の中間槽のろ液体積の減少率はP $の$ 移 動率とほぼ一致することから，中間槽内のPの大部分は イオンではなく非解離性の $\mathrm{H}_{3} \mathrm{PO}_{4}$ として存在するが，そ の状態で陽イオン回収槽と陰イオン回収槽へ移動した可 能性がある。なお，各槽の増減の収支が一致しないが， これは図-1に示すように電極槽で $\mathrm{H}_{2} \mathrm{O}$ が分解され，その 結果として生じた $\mathrm{H}_{2}$ と $\mathrm{O}_{2}$ が大気に放出されたためである.

表-2 電気透析前後での中間槽，陽イオン回収槽，陰イオン回 収槽および電極槽の溶液の体積変化と変化率（単位 : 変 化率以外はmL)

\begin{tabular}{|c|c|c|c|c|c|}
\hline \multicolumn{2}{|c|}{ 槽 } & $\begin{array}{c}\text { 陽イオン } \\
\text { 回収 }\end{array}$ & 中間 & $\begin{array}{c}\text { 陰イオン } \\
\text { 回収 }\end{array}$ & 電極 \\
\hline 透析前 & 体積 & 410 & 250 & 410 & 1100 \\
\hline \multirow{2}{*}{ 透析 } & 体積 & 464 & 196 & 470 & 1022 \\
\cline { 2 - 6 } 6hr後 & 堌減 & +54 & -54 & +60 & 78 \\
\cline { 2 - 6 } & 変化率 & 1.13 & 0.78 & 1.15 & 0.93 \\
\hline \multirow{2}{*}{$\begin{array}{c}\text { 透析 } \\
10 \text { hr後 }\end{array}$} & 体積 & 500 & 160 & 510 & 970 \\
\cline { 2 - 6 } & 増減 & +90 & -90 & +100 & -130 \\
\cline { 2 - 6 } & 変化率 & 1.21 & 0.64 & 1.24 & 0.88 \\
\hline
\end{tabular}

表-3に電気透析前後での中間槽（抽出ろ液）の元素類 の濃度を示す。電気透析前（透析時間0 hr）の濃度は下
水灰からの抽出ろ液の濃度とほぼ等しく，表-1に示した ように元素類の抽出率は，Alで97\%，Pでほぼ100\%であ った．抽出ろ液の元素類濃度はP，AsおよびPbでは電気 透析前後でほとんど変化しなかったが，他の元素類の濃 度は電気透析時間が長くなるにつれて減少する傾向がみ られ，特に共存する $\mathrm{Al} や \mathrm{Zn}, \mathrm{Cu}, \mathrm{Cd}, \mathrm{Ni}$ の除去率は透 析時間10時間で85～95\%程度に達した．電気透析前後に おいてPやAsの濃度が変化しなかった理由としては,前述 のように，これらの元素が非解離性のリン酸とヒ酸（あ るいは亜酸）として存在していたためと考えられる. 表には示していないが，抽出ろ液の硫酸イオン濃度は約 46 g/Lであり，電気透析10時間後で約 30 g/Lに減少したが, 硫酸が残存していることが分かる.

表-3 電気透析における中間槽の元素類濃度の時間変化

\begin{tabular}{|c|c|c|c|c|c|c|c|}
\hline $\begin{array}{c}\text { 透析時間 } \\
(\mathrm{hr})\end{array}$ & $\mathrm{Al}$ & $\mathrm{Ca}$ & $\mathrm{Fe}$ & $\mathrm{K}$ & $\mathrm{Mg}$ & $\mathrm{P}$ & $\mathrm{Zn}$ \\
\hline & \multicolumn{7}{|c|}{$(\mathrm{g} / \mathrm{L})$} \\
\hline 0 & 6.8 & 0.76 & 1.8 & 0.52 & 0.96 & 7.9 & 0.17 \\
\hline 6 & 2.6 & 0.13 & 0.98 & 0.39 & 0.32 & 7.8 & 0.061 \\
\hline 10 & 0.95 & 0.033 & 0.80 & 0.058 & 0.10 & 7.8 & 0.019 \\
\hline
\end{tabular}

\begin{tabular}{|c|c|c|c|c|c|c|c|}
\hline \multirow{2}{*}{$\begin{array}{c}\text { 透析時間 } \\
(\mathrm{hr})\end{array}$} & $\mathrm{As}$ & $\mathrm{Cd}$ & $\mathrm{Cr}$ & $\mathrm{Cu}$ & $\mathrm{Mn}$ & $\mathrm{Ni}$ & $\mathrm{Pb}$ \\
\cline { 2 - 8 } & \multicolumn{7}{|c|}{$(\mathrm{mg} / \mathrm{L})$} \\
\hline 0 & 1.6 & 0.30 & 5.5 & 87 & 160 & 11 & 0.009 \\
\hline 6 & 2.0 & 0.17 & 0.20 & 28 & 59 & 1.2 & 0.011 \\
\hline 10 & 1.7 & 0.040 & 1.7 & 11 & 21 & 1.0 & 0.010 \\
\hline
\end{tabular}

表-4に下水灰の元素類含有量に基づいた電気透析後中 間槽の元素類の残存率 (=電気透析後中間槽の元素濃度

（表-3） ×電気透析後中間槽の体積（表-2） $\div$ (下水灰 の元素類含有量（表-1） ×0.1 [kg-下水灰DS]））を示す. 電気透析時間が 6 時間と 10 時間で元素類の残存率を比較 すると，10時間の電気透析によってPの残存率は低下す るが，Asを除くその他の元素の残存率は10\%以下に低下 することが分かる.

表-4 電気透析後の中間槽内での元素類の残存率 $(\%)$

\begin{tabular}{|c|c|c|c|c|c|c|c|}
\hline 元素類 & $\mathrm{Al}$ & $\mathrm{Ca}$ & $\mathrm{Fe}$ & $\mathrm{K}$ & $\mathrm{Mg}$ & $\mathrm{P}$ & $\mathrm{Zn}$ \\
\hline 6hr残存率 & 29.0 & 2.5 & 12.6 & 54.6 & 24.1 & 78.6 & 11.8 \\
\hline 10hr残存率 & 8.7 & 0.5 & 8.4 & 6.6 & 6.2 & 64.2 & 3.0 \\
\hline
\end{tabular}

\begin{tabular}{|c|c|c|c|c|c|c|c|}
\hline 元素類 & \multicolumn{1}{c|}{$\mathrm{As}$} & $\mathrm{Cd}$ & \multicolumn{1}{c|}{$\mathrm{Cr}$} & \multicolumn{1}{c|}{$\mathrm{Cu}$} & \multicolumn{1}{c|}{$\mathrm{Mn}$} & \multicolumn{1}{c|}{$\mathrm{Ni}$} & $\mathrm{Pb}$ \\
\hline 6hr残存率 & 89.1 & 43.7 & 0.7 & 16.1 & 27.7 & 2.9 & 0.08 \\
\hline $10 \mathrm{hr}$ 残存率 & 61.8 & 8.4 & 4.8 & 5.2 & 8.0 & 2.0 & 0.06 \\
\hline
\end{tabular}

\section{(2) 電気透析後の抽出ろ液の固形物化とその特徵付け}

電気透析後に中間槽から取り出した抽出ろ液を $\mathrm{NH}_{3}$ 水 で中和する際の初期の溶解性金属濃度は，表-3（6時間 と10時間）に示すとおりである. 抽出ろ液を $\mathrm{NH}_{3}$ 水で中 和すると白色の懸濁物が観察された。そこで，懸濁物の みを回収してICPにより元素を分析したところ， $\mathrm{Al}, \mathrm{Fe}$ 
およびPの含有率が高かった，従って，抽出ろ液に残存 する $\mathrm{Al}$ と $\mathrm{Fe}$ が $\mathrm{PO}_{4}^{3-}$ と反応して $\mathrm{AlPO}_{4} や \mathrm{FePO}_{4}$ が生成された と考えられる.

表-5に粉末試料の元素類の全含有量および水溶性量を 示す.ここでは $\mathrm{NH}_{3}$ 水で中和後の全ての試料の乾燥固形 物の結果について述べる. Pの全含有量は $80 \mathrm{~g} / \mathrm{kg}$ 前後で あり, 電気透析時間が長いほうが若干高い值を示した.

$\mathrm{Al}$ の全含有量は電気透析 6 時間で $25 \mathrm{~g} / \mathrm{kg}, 10$ 時間で $10 \mathrm{~g} / \mathrm{kg}$ であった，KやAs，Pbにおいて水溶性量が粉末試料の全 含有量を上回る場合があったが，水溶性のP量を全含有 量に対する割合に換算すると，電気透析6時間で48\%， 10時間で93\%であった. 微量元素についてはAsの含有量 が焼却灰の含有量とほぼ等しく, ほとんどが水溶性とし て残存していることが分かる. 表には示していないが, 水溶性の $\mathrm{NH}_{4}-\mathrm{N}$ 量は電気透析6時間で130 g/kg，10時間で $140 \mathrm{~g} / \mathrm{kg}$ であった.

表-5 粉末試料の元素類の全含有量および水溶性量

\begin{tabular}{|c|c|c|c|c|c|c|c|c|c|}
\hline \multirow{2}{*}{$\begin{array}{c}\text { 透析時間 } \\
(\mathrm{hr})\end{array}$} & 抽出 & $\mathrm{Al}$ & $\mathrm{Ca}$ & $\mathrm{Fe}$ & $\mathrm{K}$ & $\mathrm{Mg}$ & $\mathrm{P}$ & $\mathrm{Zn}$ \\
\cline { 3 - 10 } & 形態 & \multicolumn{7}{|c|}{$(\mathrm{g} / \mathrm{kg}-\mathrm{DS})$} \\
\hline \multirow{2}{*}{6} & 全 & 25 & 1.1 & 10 & 0.39 & 3.2 & 79 & 0.51 \\
\cline { 2 - 10 } & 水溶性 & 0.013 & 0.22 & 0.018 & 0.78 & 2.2 & 38 & 0.030 \\
\hline \multirow{2}{*}{10} & 全 & 10 & 0.37 & 8.7 & 0.75 & 1.1 & 87 & 0.21 \\
\cline { 2 - 9 } & 水溶性 & 0.009 & 0.073 & 0.007 & 0.81 & 0.64 & 81 & 0.008 \\
\hline \multirow{2}{*}{$\begin{array}{c}\text { 透析時間 } \\
(\mathrm{hr})\end{array}$} & 抽出 & $\mathrm{As}$ & $\mathrm{Cd}$ & $\mathrm{Cr}$ & $\mathrm{Cu}$ & $\mathrm{Mn}$ & $\mathrm{Ni}$ & $\mathrm{Pb}$ \\
\hline \multirow{3}{*}{6} & 形態 & \multicolumn{7}{|c|}{$(\mathrm{mg} / \mathrm{kg}-\mathrm{DS})$} \\
\hline & 全 & 19 & 1.5 & 2.3 & 300 & 610 & 14 & 0.23 \\
\cline { 2 - 9 } & 水溶性 & 20 & 0.058 & 0.36 & 9.0 & 28 & 13 & 0.13 \\
\hline \multirow{2}{*}{10} & 全 & 22 & 0.62 & 2.4 & 110 & 220 & 11 & 0.49 \\
\cline { 2 - 9 } & 水溶性 & 27 & 0.048 & 0.67 & 0.64 & 11 & 5.3 & 0.59 \\
\hline
\end{tabular}

電気透析後の抽出ろ液を $\mathrm{NH}_{3}$ 水で中和することによっ てPの一部は抽出万液に残存する $\mathrm{Al}$ やFe と応し, 非水 溶性の $\mathrm{AlPO}_{4} や \mathrm{FePO}_{4}$ として沈殿すると仮定した場合, 沈 殿物中の $\mathrm{Al}$ と市あいはFeとPのモル比はそれぞれ1であ り, $\mathrm{Al}$ と $\mathrm{Fe}$ のル量の和と $\mathrm{P}$ のル量の比も1になる. そ こで, 電気透析6時間後と 10 時間後での固形物中の $\mathrm{Al}$,

FeおよびPの非水溶性量（=全含有量一水溶性量）をモル 量に換算し， $\mathrm{Al}$ と $\mathrm{Fe}$ のル量の和 $(\mathrm{Al}+\mathrm{Fe})$ とリンのモ ル量との比 $((\mathrm{Al}+\mathrm{Fe}) / \mathrm{P})$ を求めた（表-6）。その結果,

電気透析6時間では $(\mathrm{Al}+\mathrm{Fe}) / \mathrm{P} か ゙ 0.88$ となり，1に近い值を 示した. 従って, 電気透析6時間でPの水溶性量が低くな った原因としては，Pの一部が非水溶性の $\mathrm{AIPO}_{4} や \mathrm{FePO}_{4}$ として存在したためと考えられる.

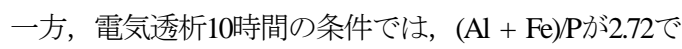
あり, PがAlやFe以外の物質と結合して存在していると 考えられる.

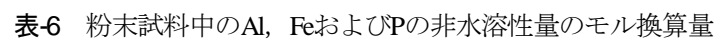
(mol/kg-DS) とモル比

\begin{tabular}{|c|c|c|c|c|c|}
\hline 透析時間 $(\mathrm{hr})$ & $\mathrm{Al}$ & $\mathrm{Fe}$ & $\mathrm{Al}+\mathrm{Fe}$ & $\mathrm{P}$ & $(\mathrm{Al}+\mathrm{Fe}) / \mathrm{P}$ \\
\hline 6 & 0.93 & 0.18 & 1.10 & 1.32 & 0.83 \\
\hline 10 & 0.37 & 0.16 & 0.53 & 0.19 & 2.72 \\
\hline
\end{tabular}

本研究で得られた粉末試料の肥料原料としての利用可 能性を評価するために, 農林水産省告示の「肥料取締法 に基づき普通肥料の公定規格を定める等の件」 ${ }^{23}$ に記載 されている「五 複合肥料」のうちの「化成肥料」に規 定されている「含有を許される有害成分の最大量

（\%）」を算出し，粉末試料の肥料成分と有害成分の含 有量との比較を行った. 表-7に粉末試料の肥料成分およ び有害成分の含有量と許容值を示す，表中のリン酸は表 -5に示すリンの全含有量を $\mathrm{P}_{2} \mathrm{O}_{5}$ 量に換算（2.3倍）して示 している.まず，「含有すべき主成分の最小量(\%)」と して「窒素, りん酸又は加里のいずれか二以上について それぞれの最も大きい主成分の量の合計量10.0」を満足 する必要があるが, 粉末試料では窒素あるいはリン酸の 含有率はいずれも10\%を超えており化成肥料としての条 件を満たした.

表-7 粉末試料の肥料成分および有害成分の含有率と許容值

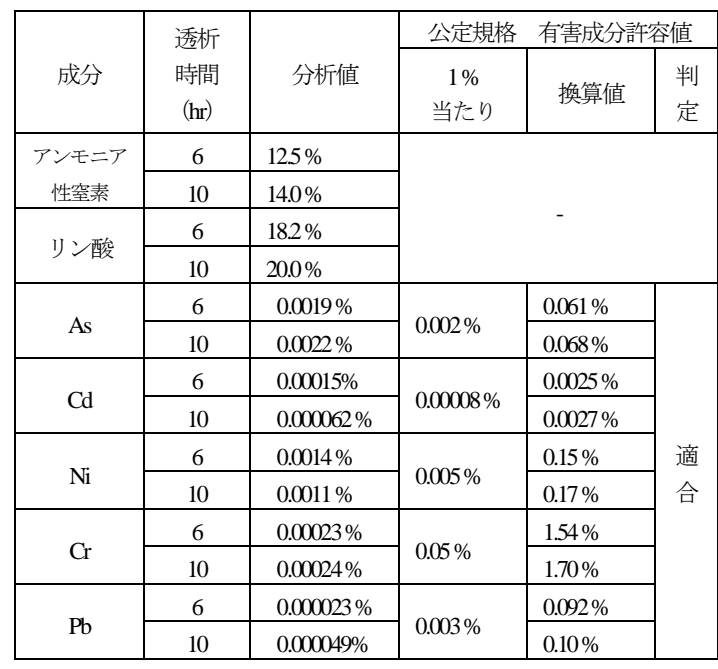

次に, 有害成分の許容值（換算值）は，粉末試料に含 まれる肥料成分（アンモニア性窒素とリン酸）の含有率 の合計值（例えば，6時間の粉末試料の場合，30.7\%）に 各有害成分に定められている肥料成分 $1 \%$ 当たりの許容 值を乗じて求める（例えば，Asであれば $30.7 \% \times$ $0.002 \%=0.061 \%$ ）。粉末試料の分析值が許容值（換算 值）を下回れば適合として判定できる. 結果をみると, 本研究で検討した有害成分の分析值は, 全ての項目で許 容值（換算值）を充分に下回っていた. 表-3に示すよう 
に電気透析による有害成分 (As， Cd， Ni， CrおよびPb) の除去率は最大でも $85 \%$ 程度であり, 電気透析を行わな ずに有害成分が残留し，表-6に示寸分析值が10倍程度に 増加したとしても許容值を十分に満足できるが，電気透 析を行うことによって, より安全な肥料原料を得ること ができると考えられる.

なお，「化成肥料」に対する有害成分としては，表-7 に示した項目に加えて「硫青酸化物」,「亜硝酸」,

「ビウレット性窒素」，「スルファミン酸」も定められ ているが，ここでは分析を行わなかった．また，「チタ ン」と「水銀」も定められているが，電気透析の条件が 異なる他の粉末試料について分析した結果では許容值を 充分に下回っており, 同粉末を用いた植害試験の結果も 問題が無いことを確認している.

図-3に10時間の電気透析処理によって得られた粉末試 料之標準物質のX線回折パターンを示寸. なお，標準物 質の回折パターンは, 統合粉末X線解析ソフトウェアの PDXL（Rigaku）より入手可能なデータベースと，国立 研究開発法人 物質 - 材料研究機構, Mat Navi, 無機材料

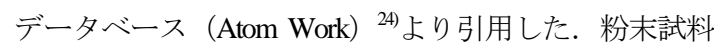
の回折パターンに最も合致する物質は $\left(\mathrm{NH}_{4}\right)_{2} \mathrm{SO}_{4}$ であり， リン化合物の中では $\mathrm{NH}_{4} \mathrm{H}_{2} \mathrm{PO}_{4}$ と $\mathrm{P}_{2} \mathrm{O}_{5}$ が比較的合致した.

図は示さないが，6時間の電気透析処理で得られた粉末 試料の回折パターンと比較すると $\mathrm{NH}_{4} \mathrm{H}_{2} \mathrm{PO}_{4}$ と $\mathrm{P}_{2} \mathrm{O}_{5}$ に現れ る相対強度のピークは10時間の粉末の方が大きかった。

モノクロでは識別が難しいため図は示さないが，FESEMとEDXによる元素マッピング分析の結果では, 粉末 結晶表面のPの分布はNの分布と重なる部分とそうでな い部分の双方が観察された. 従って, 粉末試料中のリン はリン酸アンモニウムだけではなく, X線回折パターン で確認された $\mathrm{P}_{2} \mathrm{O}_{5}$ のような化合物としても存在している 可能性が示された.

図-4に本研究で提案する下水灰からのリン回収プロセ スのフローを示寸. 実際の処理では, 抽出, 固液分離, 電気透析, 中和及び乾燥のための各設備が必要であると ともに, 薬剤 (硫酸, 中和剂) やエネルギー（電気と 熱)，設備の維持管理（イオン交換膜など）などのラン ニングコストが必要になる. 今後は実用化に向けた電気 透析装置の改良と連続運転を検討し，処理コストを算出 する必要がある.

以上の結果から，本プロセスを通じて下水灰中のリン の6割程度を化成肥料の原料として利用可能な水溶性リ ン酸塩として回収できることが分かり，本プロセスの有 用性を明らかにすることができた.

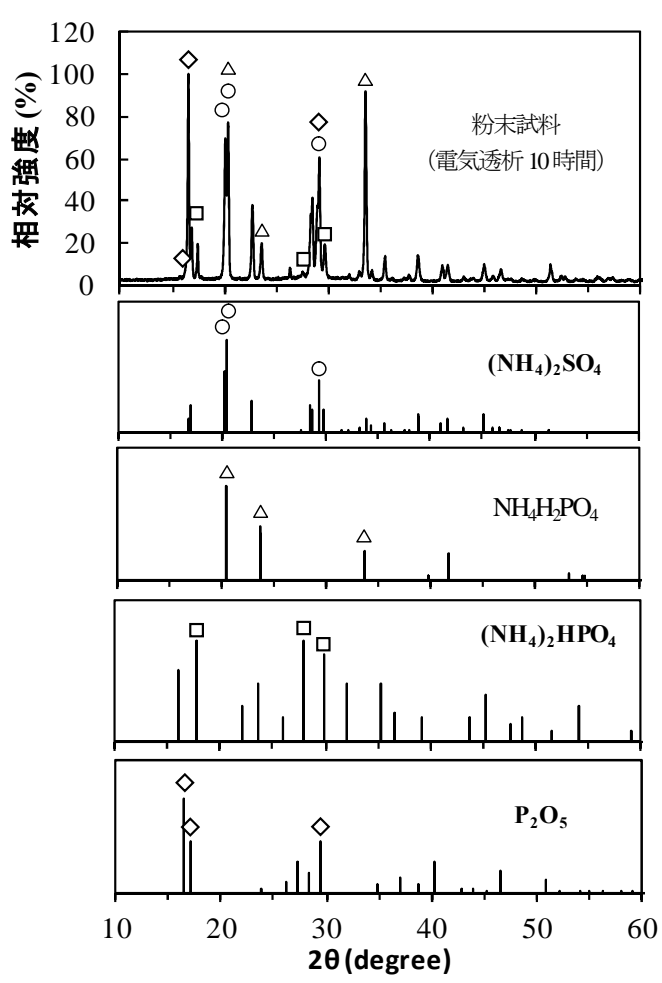

図-3 粉末試料と標準試料のX線回折パターン（電気透析時 間 : 10時間)

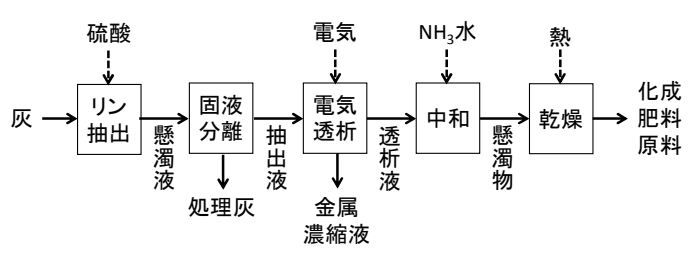

図-4 下水灰からのリン回収プロセスのフロー

\section{4. まとめ}

本研究では下水灰の硫酸抽出ろ液を電気透析で処理し, そのろ液を $\mathrm{NH}_{3}$ 水で中和した後, 乾燥粉末として回収し, その肥効性と構成成分の推定を調查した. 以下に得られ た結果を示す.

1) 下水灰の硫酸抽出ろ液の $\mathrm{pH} 0.5$ に維持しながら電気 透析を10時間行うことによって Alの約95\%を除去し つつ, $\mathrm{P}$ の0\%を保持できた. また, 共存するZnや $\mathrm{Zu}$ についても $85 \%$ 程度の除去率が得られた。

2) 電気透析後のろ液を $\mathrm{NH}_{3}$ 水で中和することで白色の懸 濁物が生じ，その懸濁液を乾燥することで固形物と して回収できた. 固形物の粉末試料に含まれる水溶 性リンの含有量は透析時間が長い方が高くなった. 
3) 粉末試料に含まれる窒素とリン酸の量は化成肥料に求 められている量を上回り，一方，有害成分の許容量 を下回っており，化成肥料の原料として利用できる 可能性が示された.

4) X線回折装置とFE-SEMおよびEDXによる粉末試料の分 析の結果から, 粉末試料の大部分は $\left(\mathrm{NH}_{4}\right)_{2} \mathrm{SO}_{4}$,

$\mathrm{NH}_{4} \mathrm{H}_{2} \mathrm{PO}_{4}$ および $\mathrm{P}_{2} \mathrm{O}_{5}$ から構成されていると推察され た.

以上の結果から, 下水灰からの硫酸抽出ろ液を電気透 析で処理し，そのろ液を $\mathrm{NH}_{3}$ 水で中和して乾燥すること によって, 下水灰から硫安と燐安の複合的な化成肥料の 原料を回収できることが分かった.

謝辞 : 本研究の一部は, 農林水産省「新たな農林水産政 策を推進する実用技術開発事業」（課題番号 : 23012, 課題名:下水灰の肥料用原料化技術の開発研究）からの 補助を受けて実施した。ここに記して謝意を表する。ま た, 岩手大学工学部社会環境工学科環境衛生工学研究室 の所属学生である高橋健太氏, 伊藤美穂氏, 並びに及川 俊文氏の協力を得た。ここに謝意を表する.

\section{参考文献}

1) 国土交通省都市・地域整備局下水道部：下水道にお けるリン資源化の手引き, 2010.

2) 太田太一: 下水污泥有効利用の現状と推進に向けた 取組，再生と利用，Vol.40，No.151，pp.25-34， 2016.

3) 高橋泰弘, 吉田佳子, 洙田泰臣, 曾根庸夫 : 污泥焼 却灰に含まれる有価物の効率的な回収に関する研究, 下水道協会誌，Vol.38，No.468，pp.181-192， 2001.

4) 吉田佳子, 高橋泰弘, 洙田泰臣, 宇城碩弥 : 污泥焼 却灰のリンとアルミニウムの実用的な回収に関する 研究, 下水道協会誌, Vol.39, No.482, pp.107-120, 2002.

5）高橋泰弘：下水污泥焼却灰のアルカリ溶出特性, 廃 棄物学会論文誌, Vo.15, No.6, pp.491-499, 2004.

6）伊藤歩, 山田浩司, 武田祐介, 北田久美子, 相澤治 郎, 海田輝之: 下水污泥焼却灰に含まれる重金属類 の溶出に関寸る研究, 下水道協会誌, Vol.37, No.458, pp.166-180, 2000.

7) Takahashi, M., Kato, S., Shima, H., Sarai, E., Ichioka, T., Hatyakawa, S. and Miyajiri, H.: Technology for recovering phosphorus from incinerated wastewater treatment sludge, Chemosphere, Vol.44, No.1, pp.23-29, 2001.

8) 大下和徹, 岩下真理, 高岡昌輝, 武田信生 : 下水污 泥焼却灰からの湿式リン抽出方法の体系化, 環境工 学研究論文集, Vol.40, pp.395-404, 2003.

9）高島正信：焼却灰および嫌気性消化污泥からの酸溶 出によるリン・重金属の分別回収, 土木学会論文集 G (環境)，Vol.67, No.7, pp.III_467-III_473， 2011.

10) Ito, A., Yamada, K., Ishikawa, N. and Umita, T.: Separa- tion of metals and phosphorus from incinerated sewage sludge ash, Wat. Sci. Technol., Vol.67, No.11, pp.24882493, 2013.

11) Ottosen, L. M., Kirkelund, G. M. and Jensen, P. E.: Extracting phosphorous from incinerated sewage sludge ash rich in iron or aluminum, Chemosphere, Vol.91, No.7, pp.963-969, 2013.

12) Franz, M.: Phosphate fertilizer from sewage sludge ash (SSA), Waste Management, Vol.28, No.10, pp.1809-1818, 2008.

13) Biswas, B. K., Inoue, K., Harada, H., Ohto, K. and Kawakita, H.: Leaching of phosphorus from incinerated sewage sludge ash by means of acid extraction followed by adsorption on orange waste gel, J. Environ. Sci., Vol.21, No.12, pp.1753-1760, 2009.

14) Donatello, S., Tong, D. and Cheeseman, C. R.: Production of technical grade phosphoric acid from incinerator sewage sludge ash (ISSA), Waste Management, Vol.30, No.8-9, pp.1634-1642, 2010.

15) Guedesa, P., Coutoa, N., Ottosen, L. M. and Ribeiroa A. B.: Phosphorus recovery from sewage sludge ash through an electrodialytic process, Waste Management, Vol.34, No.5, pp.886-892, 2014.

16) Ebbers, B., Ottosen, L. M. and Jensen, P. E.: Comparison of two different electrodialytic cells for separation of phosphorus and heavy metals from sewage sludge ash, Chemosphere, Vol.125, pp.122-129, 2015.

17) Ottosen, L. M., Jensen, P. E. and Kirkelund G. M.: Phosphorous recovery from sewage sludge ash suspended in water in a two-compartment electrodialytic cell, Waste Management, Vol.51, pp.142-148, 2016.

18）川上北斗, 伊藤美穂, 高橋健太, 伊藤歩, 石川奈 緒・海田輝之：リン回収を目的とした下水污泥焼却 灰硫酸抽出液からの金属類の除去, 第 51 回環境工学 研究フォーラム講演集, pp.182-184, 2014

19）（公社）日本下水道協会 : 下水試験方法 上巻-2012 年 版-, 2012.

20) 松尾友矩 編 : 大学土木 水環境工学 改訂 3 版, オーム 社, 2014.

21）（独）農林水産消費安全技術センター（FAMIC）： 肥料分析法（農林水産省農業環境技術研究所法）1992 年版-, 1992.

22) 井出哲夫 編 : 水処理工学 理論と応用, 技法堂出版, 1990.

23）（独）農林水産消費安全技術センター（FAMIC）： 肥料取締法に基づき普通肥料の公定規格を定める等 の)

( http://www.famic.go.jp/ffis/fert/kokuji/60k0284.htm ) （アクセス日：2016年 5 月 18 日）。

24）(国研法）物質・材料研究機構 : Mat Navi, 無機材料デー タベース（Atom Work）（http://mits.nims.go.jp/）（アクセス 日：2016年3月 1 日）.

(2016.5.26 受付) 


\section{ELECTRODIALYTIC METALS REMOVAL AND FORMATION OF WATER SOLUBLE PHOSPHATE FROM ACIDIC EXTRACT OF SEWAGE SLUDGE INCINERATED ASH}

\section{Ayumi ITO, Hokuto KAWAKAMI, Nao ISHIKAWA, Tokumi Mochiyama, Shuichi OCHI and Teruyuki UMITA}

Firstly, the metals removal from acidic extract of sewage sludge incinerated ash was investigated using an electrodialyzer. Through the elecrtodialysis at a $\mathrm{pH}$ of 0.5 during 10 hours, about $90 \%$ of $\mathrm{Al}, \mathrm{Zn}$ and $\mathrm{Cu}$ in the extract were removed, while $60 \%$ of $\mathrm{P}$ was retained in the extract. Secondly, the extract after the electrodialysis was neutralized with $28 \%$ ammonia water and was dried at $45^{\circ} \mathrm{C}$. The water soluble phosphorus content of the dried sample was about $90 \%$. The composition of the dried sample met the quality criteria required for the chemical fertilizer. The analyses of the dried powder sample with the XRD and FESEM-EDX showed that the dried sample would be mainly composed of $\left(\mathrm{NH}_{4}\right)_{2} \mathrm{SO}_{4},\left(\mathrm{NH}_{4}\right) \mathrm{H}_{2} \mathrm{PO}_{4}$ and $\mathrm{P}_{2} \mathrm{O}_{5}$. These findings suggest that the dried sample recovered from acidic extract of the sewage sludge ash could be recycled as a raw material of fast acting fertilizers. 